\title{
Enemy Films on Soviet Screens: trophy films during the early Cold
}

\section{War, 1947-52}

\author{
Claire Knight, University of Oxford*
}

\section{Introduction}

The Soviet Union fought a cultural war on two fronts during the final years of Stalin's leadership. The first front faced inward, against the legacy of the Great Patriotic War and how it was won: against the effects of wartime liberalization and fraternization with the West. The second front faced outward, against the infiltration of Western culture in the context of the emerging Cold War. Among the key weapons wielded by the Soviet regime were intensified censorship, administrative centralization, and a series of political campaigns - the Zhdanovshchina, anti-kowtowing [nizkopoklonstvo] to the West, and anti-cosmopolitanismintended to purge Soviet artistic and intellectual life of cultural heterodoxy or the "alien" influences of the West and Jews. ${ }^{1}$ The ammunition consisted of policies as diverse in their targets and caliber as the banning of specific films, authors and jazz music, outlawing marriage to a foreigner, prosecuting scientists in sudy chesti (honor courts) for sharing findings with Western colleagues, and subjecting Red Army former prisoners of war to filtratsiia (filtration) and internment in order to contain those tainted by contact with the West. ${ }^{2}$ It was

\footnotetext{
* I would like to thank the Social Sciences and Humanities Research Council of Canada and the Royal Historical Society for making the research for this article possible. I am also indebted to the anonymous reviewers of this piece for their constructive feedback, particularly that of the scholar who engaged so closely with the conceptual framework. All translations are the author's, except where noted otherwise. ${ }^{1}$ For a succinct overview of these metamorphosing campaigns, see: Frank Grüner, "Russia's Battle against the Foreign": The Anti-Cosmopolitanism Paradigm in Russian and Soviet Ideology', European Review of History, 17 (2010), 445-72 (pp. 450-60).

${ }^{2}$ Rossiiskii gosudarstvennyi arkhiv sotsial'no-politicheskoi istorii (RGASPI) f. 17, op. 116, d. 277, 1l. 30-34 (Postanovlenie Orgbiuro TsK VKP(b) o kinofil'me "Bol'shaia zhizn"”, 4 September 1946), reprinted in K.M. Anderson and L.V. Maksimenkov, Kremlevskii kinoteatr: 1928-1953: dokumenty (Moscow: ROSSPEN, 2005), 763767. Martin Lücke, "The Postwar Campaign against Jazz in the USSR (1945-1953)," in Fazz behind the Iron Curtain, ed. Gertrud Pickhan and Rüdiger Ritter, Jazz under State Socialism (Frankfurt: Peter Lang, 2010), 8398; George Ginsburgs, The Citizenship Law of the USSR, vol. 25, Law in Eastern Europe (BRILL, 1983), 53; Mark
} 
a battle of recovery and defense; a struggle to re-establish Soviet cultural orthodoxy and reveal the paucity of Western culture.

It is in this context of cultural defense that we find one of the most paradoxical phenomena of the Cold War period, namely the screening of Western films in the USSR. From early 1947 until Stalin's death, films from the capitalist dream factories of Hollywood and Nazi Germany were screened at a rate nearly commensurable with that of new Sovietmade productions, enlivening screens from Moscow to Altai, Moldova to Georgia, Latvia to Azerbaijan. The foreign films were known as trofeinye fil'my (captured "trophy" films) since they were drawn from among the 10,669 films captured by the Red Army primarily from the Reichsfilmarchiv in Berlin in $1945 .^{3}$ They were tremendously popular with Soviet audiences, as attested by the wealth of colorful anecdotes peppering memoirs of the period, ${ }^{4}$ but it is the mere fact of their existence that has most bemused scholars of Soviet cinema. Studies have been quick to note the pragmatic function of trophy films: their release coincided with the dearth in domestic film production known as malokartin'e or film famine during which, in 1951, the number of new Soviet-made releases dropped to an all-time low of nine. Trophies

Edele, Soviet Veterans of World War II: A Popular Movement in an Authoritarian Society, 1941-1991 (Oxford University Press, 2008), 102-03. The most well-known honor court trial involved cancer researchers Nina Kliueva and Grigorii Roskin, see Nikolai Krementsov, The Cure: A Story of Cancer and Politics from the Annals of the Cold War (Chicago: University of Chicago Press, 2004).

3 These unlicensed trophy films screened until 1956. For more on the origins and precise composition of the trophy film collection, see: Claire Knight, "Stalin's Trophy Films, 1947-52: A Resource," KinoKultura, no. 48 (2015), http://www.kinokultura.com/2015/48-knight.shtml; Ministerstvo kul'tury SSSR, "Catalogue of Foreign Sound Films Released on the Soviet Screen, 1927-1954," trans. Richard Taylor, Studies in Russian and Soviet Cinema 10, no. 2 (May 3, 2016): 123-98.

${ }^{4}$ Key memoirs for trophy film anecdotes include: Joseph Brodskii, "Trofeinoe (1986)," in Istoriia otechestvennogo kino: khrestomatiia, ed. A.S. Troshin (Moscow: Kanon+, 2012), 418-21; Vassily Aksyonov, In Search of Melancholy Baby, trans. Michael Henry Heim and Antonina Bouis (New York: Random House, 1987); Bulat Okudzhava, Devushka moei mechty: avtobiograficheskie povestvovaniya (Moscow: Moskovskii rabochii, 1988). For interviews mentioning trophy films, see Juliane Fürst, Stalin's Last Generation: Soviet Post-War Youth and the Emergence of Mature Socialism (Oxford: Oxford University Press, 2010), pp. 205-209, 237; Mark Edele, 'Strange Young Men in Stalin's Moscow: The Birth and Life of the Stiliagi, 1945-1953', Fahrbücher für Geschichte Osteuropas, 50 (2002), 3761 (pp. 53-56); Timothy Johnston, Being Soviet: Identity, Rumour, and Everyday Life under Stalin, 1939-1953, Oxford Historical Monographs (Oxford: Oxford University Press, 2011), pp. 191-198, 206; Frederick H. White, 'Tarzan in the Soviet Union', The Soviet and Post-Soviet Review, 42 (2015), 64-85 (pp. 66-68). A few respondents in the Harvard Émigré Interview Project, conducted from 1951-53, also describe trophy films. See "Harvard Project on the Soviet Social System," Davis Center for Russian and Eurasian Studies, accessed December 20, 2014, http://daviscenter.fas.harvard.edu/library/research-guides/archival-sources-soviet-history/hpsss. 
were used to keep the cinema industry alive and the war weary masses entertained. ${ }^{5}$ More recently, supposition as to the appeal of the profitability of trophy screenings for the Politburo has been confirmed by Natacha Laurent, providing a more cynical rationale for the screening of what were essentially enemy films in early Cold War USSR. ${ }^{6}$

These pragmatic explanations are in need of further scrutiny and elaboration - an endeavor that this article undertakes. But they also require supplementation, for by their reckoning trophy films were at best a compromise in the face of financial deficit and domestic production problems. By eschewing a discussion of the ideology of trophy films, the pragmatic and economic emphases of existing scholarship convey only a partial account of official motivations for releasing these films and risk distorting the regime's perspective on cinema and cultural production. After all, by the postwar period sharp distinctions were no longer being made between the entertainment, commercial, and "enlightenment" or political educational functions of films. Such a synthesis had been some time in the making, for while the early Bolshevik approach recognized the interdependence of these various aspects of the cinema industry as a whole, it failed to do so in relation to individual films. For instance, Lenin's 1922 statement on the usefulness of entertainment films for generating revenue and attracting an audience for the accompanying "films of a particularly propagandist content"7 that were intended to flesh out cinema programs (according to the so-called "Lenin proportion"8), assumes that individual films were either attractional or educational in function - not both. This contrast was maintained by proponents on either side of the

\footnotetext{
${ }^{5}$ Peter Kenez, Cinema and Soviet Society, 1917-1953 (Cambridge: Cambridge University Press, 1992), 213-214; Maya Turovskaya, "The 1930s and 1940s: Cinema in Context," in Stalinism and Soviet Cinema, ed. Richard Taylor and Derek Spring (New York: Routledge, 1993), 51; Richard Taylor, Film Propaganda: Soviet Russia and Nazi Germany, 2nd ed. (I.B. Tauris, 1998), 48-49; White, "Tarzan in the Soviet Union," 78.

${ }^{6}$ Natacha Laurent, L'œil Du Kremlin: Cinéma et Censure en URSS sous Staline, 1928-1953 (Toulouse: Privat, 2000), pp. 234-239. See also Sergei Kapterev, "Illusionary Spoils: Soviet Attitudes toward American Cinema during the Early Cold War," Kritika: Explorations in Russian and Eurasian History 10, no. 4 (2009): 790; Kristin Roth-Ey, Moscow Prime Time: How the Soviet Union Built the Media Empire That Lost the Cultural Cold War (Ithaca: Cornell University Press, 2011), 39-43.

${ }^{7}$ Lenin quoted in Ian Christie and Richard Taylor, eds., The Film Factory: Russian and Soviet Cinema in Documents 1896-1939 (London: Routledge, 1994), 56.

8 Ibid., 121.
} 
"entertainment or enlightenment debate" that dominated Soviet discussions of cinema throughout the 1920s, ${ }^{9}$ until it was finally resolved under the leadership of Boris Shumiatskii, who was made chairman of the central cinema organization, Soiuzkino, in 1930. Shumiatskii advocated integrating the hitherto opposing aims of entertainment and political education into a unified ideal to be aspired to by each film production, though this was rarely achieved in practice. ${ }^{10}$

It was in this context of the synthesis of entertainment and education in individual films that trophy films were conceived, processed and screened, and it is in this context that they must be analysed. Instead of considering postwar trophy films as a product of a revived 1920s distinction between entertaining and enlightening cinema, this study examines the place of trophy films in a cinema tradition that had striven since the release of Chapaev (Vasil'ev "Brothers", 1934) to create "clear ideological content wrapped in a cloak of entertainment". ${ }^{11}$ This approach necessitates a conceptualization of trophy films as Soviet products - formed by Soviet editors for Soviet audiences according to the priorities and practices of the Soviet regime- and not simply foreign films.

In this light, it becomes clear that the apparent aberration of trophy films were in fact congruent with the state's postwar policies reconsolidating Soviet culture and waging the burgeoning "culture war"12 with the West. This is because trophy films were a quintessential example of the Cold War tactic of negative self-definition. Recent scholarship on comparative Cold War cultures has established that negative definitions of cultural identity were crucial

\footnotetext{
${ }_{9}^{9}$ Denise Youngblood, Movies for the Masses: Popular Cinema and Soviet Society in the 1920s (Cambridge: Cambridge University Press, 1993), 35-49.

${ }^{10}$ Richard Taylor, "Soviet Cinema as Popular Culture: Or the Extraordinary Adventures of Mr Nepman in the Land of the Silver Screen," Revolutionary Russia 1, no. 1 (June 1, 1988): 45-46; Jamie Miller, Soviet Cinema: Politics and Persuasion Under Stalin, 1st edition (I. B. Tauris, 2010), 49.

11 Taylor, "Soviet Cinema as Popular Culture," 46.

12 David Caute, The Dancer Defects: The Struggle for Cultural Supremacy during the Cold War (Oxford: Oxford University Press, 2003), 1; Kathleen Starck, "Introduction," in Between Fear and Freedom: Cultural Representations of the Cold War, ed. Kathleen Starck (Newcastle: Cambridge Scholars, 2010), 3.
} 
during the 45 -year conflict, ${ }^{13}$ meaning that the competing political systems defined themselves in terms of not only what they were, but also what they were not. For instance, in Soviet films set partially in the West such as The Russian Question (Russkii vopros, Romm, 1948) and Sport Honor (Sportionaia chest', Petrov, 1951), the corruption and deprivation evident under capitalism serve to highlight the equity and opportunity inherent in Soviet society. Through the careful reprocessing and presentation of trophy films, the Soviet regime sought to use the cinematic production of the West to condemn it, revealing the flaws of capitalist society through its own films and implicitly exonerating Soviet culture as its antithesis. In this way, screening enemy films not only made good economic sense, but also presented a prime opportunity to propagandize the Soviet way of life.

What follows, then, is a reevaluation of trophy film, beginning with a thorough examination of the financial and practical interests driving their release, followed by an investigation into what was essentially the official Soviet response to the question of whether foreign cultural production could be conformed to the aims of a cinema industry focused on combining entertainment and Soviet ideology. This question will be considered not only from the regime's perspective, however, but also from that of Soviet viewers whose impressions of trophy films - recorded in memoirs, interviews and archives - will be scrutinized in order to ascertain the extent to which popular perceptions of the repackaged foreign films aligned with official intentions in screening enemy films during the early Cold War.

\section{The Timeliness \& Profitability of Trophy Films}

Trophy film releases were both timely and profitable, playing a key role in maintaining the Soviet cinema industry. However, such lofty potential initially went unrecognized by the regime. For although foreign films had provided a valuable source of revenue with which to

\footnotetext{
13 Patrick Major and Rana Mitter, "East Is East and West Is West? Towards a Comparative Socio-Cultural History of the Cold War," in Across the Blocs: Cold War Cultural and Social History, ed. Patrick Major and Rana Mitter (London: Frank Cass, 2004), 7.
} 
subsidize revolutionary cinema during the 1920s, film imports had been abandoned by the mid-1930s, leaving socialist realist fare alone to enlighten Soviet audiences. This policy of cinematic autarky was amended during the war, allowing for film exchanges with the Allies that totaled five to eight titles per year. ${ }^{14}$ It was this moderate approach to foreign film import that originally set the pattern for trophy film releases, ${ }^{15}$ as six trophies were edited, dubbed or subtitled, and screened in 1947, and initially another six planned for release in 1948.

This measured approach soon changed dramatically, with 50 trophy films approved for processing on 31 August 1948. The timing of this decision was significant as it came ten weeks after the introduction of the policy of "fewer but better films" that drastically reduced the number of titles approved for development by Soviet studios in order to concentrate the industry's investment on the creation of masterpieces. ${ }^{16}$ The policy was ratified as part of the 14 June 1948 film production plan, which also included the only reference in such a plan during the late Stalin era to foreign films (i.e. the second set of six trophies mentioned above). It is possible that this juxtaposition indicates a sensitivity on the part of the Ministry of Cinema and Central Committee to the need to offset the impact of the "fewer but better" policy and bolster film release rates with foreign titles. The Minister of Cinema Ivan Bol'shakov was careful to select the types of films that he deemed would be pleasing to Soviet audiences, ${ }^{17}$ drawing films primarily from the most popular but least represented genres in

\footnotetext{
${ }^{14}$ Youngblood, Movies for the Masses, 64; Vladimir Kozlov, "Spisok Amerikanskikh fil'mov v sovetskom i rossiiskom prokate 1929-1998," Kinograf, no. 16 (2005): 176. RGASPI f. 17, op.125 (Papers of the Department of Agitation and Propaganda), d. 576, l. 3 (letter from I. G. Bol'shakov to A. A. Zhdanov, 14 March 1947).

${ }^{15}$ RGASPI f. 17, op. 125, d. 576, 1. 3.

${ }^{16}$ The "fewer but better" strategy of film production marked a deliberate policy change rather than simply the ratification of an existing trend. For although postwar shortages and other challenges, not to mention the increasingly labyrinthine censorship system, did retard film production during the late Stalin era, release rates had actually recovered in the initial postwar years, with 18 films in 1946, 24 in 1947, and 22 in 1948. It was not until after the introduction of the "fewer but better" policy in mid-1948 that domestic releases plummeted to the dismal figures characteristic of malokartin'e: 12 in 1949, 13 in 1950, 9 in 1951, and 10 in 1952 (excluding filmed concerts and theatrical performances). These figures are based on the release dates for domestic film productions compiled in Aleksandr Veniaminovich Macheret, ed., Sovetskie khudozhestvennye fil'my: annotirovannyi katalog: vol. 2 zvukovye fil my, 1930-1957 (Moscow: Iskusstvo, 1961).

${ }^{17}$ RGASPI f. 17, op. 125, d. 576, l. 3.
} 
postwar Soviet film - musicals and adventures — thereby filling a gap in domestic production. ${ }^{18}$

The wide-scale release of trophy films also filled the coffers, which was a decided boon at a time when the film industry was being subjected to close budgetary scrutiny with the intent of using profits to finance postwar reconstruction. As Laurent notes, it was in this context that a discourse of profitability emerged in Ministry of Cinema correspondence, ${ }^{19}$ while concern for cost-effectiveness helped fuel intensified censorship. Trophy films, with their lack of licensing fees, minimal processing costs and most importantly, box office draw, presented an ideal scenario for the budget conscious Ministry of Cinema, as the majority of scholarly references to trophy film imply. ${ }^{20}$ It is clear from the 31 August 1948 resolution that the Central Committee was aware of the economic potential of screening foreign films, since it required Bol'shakov to guarantee personally that the films would garner a profit of no less than 750 million rubles. ${ }^{21}$ It seems to have been Bol'shakov himself who first stressed the financial benefits of the unlicensed pictures. On 5 August 1948, he proposed to Deputy Chairman of the Council of Ministers Georgii Malenkov the release of Captain of the Army 'Freedom' (Kapitan armii 'Svoboda', 1948; Viva Villa! Conway, 1934), concentrating exclusively on the financial argument: he anticipated a revenue of 35-40 million rubles if circulated $n a$ zakrytyi ekran, through the "closed" network of workers' clubs and houses of culture, or 50-60

\footnotetext{
${ }^{18}$ A mere eight Soviet-made adventure films premiered during 1945-52, of which only six were on wide release, while Aleksandrov's Spring (Vesna, 1947) and Pyr'ev's Cossacks of the Kuban (Kubanskie kazaki, 1950) were the only proper musicals - meaning that they were advertised specifically as musical comedies and featured songs with lyrics relevant to the plot. In contrast, 24 musicals and 17 adventures were released from among the trophy archive, constituting $47.1 \%$ of trophy releases. Knight, "Stalin's Trophy Films."

${ }^{19}$ Laurent, L'ail, 225. In 1946, the cinema industry turned a profit of three billion rubles, two billion of which were directed into reconstruction. Ibid., 226.

${ }^{20}$ Kenez, Cinema and Soviet Society, 213; Fürst, Stalin's Last Generation, 206; Roth-Ey, Moscow Prime Time, 43; Maiia Turovskaia, "Gollivud v Moskve, ili Sovetskoe i amerikanskoe kino 30-kh-40-kh godov," Kinovedcheskie zapiski 97 (2010): 59; Johnston, Being Soviet, 189; Mark Edele, Stalinist Society, 1928-1953 (Oxford: Oxford University Press, $2011), 155$.

${ }^{21}$ RGASPI f. 17, op. 3, d. 1072, 1l. 31-32 (Postanovlenie Politbiuro TsK VKP(b) o vypuske na ekran zagranichnykh kinofil'mov iz trofeinogo fonda, 31 August 1948), reprinted in Andrei Artizov and Oleg Naumov, eds., Vlast'i khudozhestvennaia intelligentsiia: dokumenty TSK RKP(b)-VKP(b), VChK-OGPU-NKVD o kul'turnoi politike: 1917-1953 gg. (Moscow: Demokratiia, 1999), 639-40.; Laurent, L'œil, 236.
} 
million if screened publicly, na shirokii ekran. ${ }^{22}$ It is possible that this attractive set of figures inspired Malenkov and the Central Committee to require, four days later, that Bol'shakov provide a lengthy list of potential releases from the trophy collection, from which were drawn the fifty titles approved on 31 August. Subsequently, the Minister of Cinema embraced larger scale plans for trophy film processing and returned to Malenkov six months later requesting a second lot of fifty releases in order to address a shortfall in the Ministry's yearly profit plan. ${ }^{23}$ Twenty-five films were eventually approved in the resolutions of 7 May and 9 June 1949. These documents also demanded profit guarantees from the Minister of Cinema, totaling 430 million rubles, indicating that revenue expectations had inflated. ${ }^{24}$ In this way, while the financial incentive for trophy film processing was first voiced by a budget conscious Minister, the initiative to undertake large scale trophy distribution rested with the revenue-minded Central Committee.

The expectations of the Central Committee concerning the profitability of trophy films were well founded, as both anecdotal evidence and the archival record confirm. "The first of May Demonstration was nothing in comparison with the queue for tickets when an American film opened," ${ }^{25}$ recalls memoirist Valentin Tikhonenko. It was doubtless such enthusiasm that inspired cinema managers to maximize the number of showings per day and extend as long as possible the overall runs of the foreign pictures. First secretary of the Komsomol Central Committee Nikolai Mikhailov noted this trend with consternation, complaining to the Department of Agitation and Propaganda (Agitprop) of the foreign films' monopoly on screens across the Soviet Union. He made reference to the cinema Oktiabr in Barnual' (Altai), which showed five foreign films for a total of 45 days, while Chiaureli's Stalin

\footnotetext{
22 Laurent, L'œil, 236.

${ }^{23}$ RGASPI f. 17, op. 132 (Agitprop), d. 249, 1.57 (I. G. Bol'shakov to V. M. Molotov, 18 March 1949).

${ }^{24}$ RGASPI f. 17, op. 3, d. 1075, 1l. 82-83 (Postanovlenie Politbiuro TsK VKP(b) o vypuske na ekran zagranichnykh kinofil'mov iz trofeinogo fonda, 7 May 1949), f. 17, op. 3, d. 1076, 1. 41 (Postanovlenie Politbiuro TsK VKP(b) o vypuske na ekran zagranichnykh kinofil'mov iz trofeinogo fonda, 9 June 1949). Both documents are reprinted in Artizov and Naumov, Vlast'i khudozhestvennaia intelligentsïa, 651-52.

${ }^{25}$ Olesia Guk, "Tarzan v svoem otechestve: Valentin Tikhonenko," Pchela 11 (November 1997), http://www.pchela.ru/podshiv/11.htm. Translation by:Johnston, Being Soviet, 198.
} 
epic The Vow (Kliatva, 1946) entertained audiences for only two days, and the re-release of Romm's classic Lenin in October (Lenin v Oktiabr, 1937), only one day. Meanwhile in Riga, he continued, screenings of the German musical Girl of my Dreams (Devushka moei mechty, 1947; Die frau meiner träume [The Woman of my Dreams], Jacoby, 1944) ${ }^{26}$ began at 11 am and continued for over 15 hours. ${ }^{27}$ It was intensive showings like this that enabled the Marika Rökk musical to out-screen the domestic hit, Secret Agent (Podvig razvedchika, Barnet, 1947), by a factor of five (on a per copy basis), as film historian Maia Turovskaia calculated. ${ }^{28}$ In total, the film garnered 15.7 million ticket sales in its first year. This was actually a relatively low figure compared with the other trophy films for which box office data are available, with average ticket sales of 27.6 million each, out-selling the average domestic production by 4 million. ${ }^{29}$ The four Tarzan films released in 1952 were particularly successful, earning between 38.6 million and 42.9 million ticket sales each, making them the top selling films of the late Stalin period.

Added to the profitability of trophy films, was also their cost-effectiveness. Not only were trophy production costs negligible - requiring simply the services of translators, editors, and in the case of the German films (which were dubbed and distributed on the public network of cinemas in contrast to the American films, which were subtitled and circulated on the closed network), voice actors - but the films also avoided much of the costly, timeconsuming process of censorship. This process, according to a report by Minister of State Control Lev Mekhlis in May 1948, involved alarming expenditures, adding its own form of financial wastage to cinematic production. For instance, he calculated that in 1947 the

\footnotetext{
${ }^{26}$ Where the Soviet release date of a trophy film is not indicated in the body of the text, it will be noted after the Russian title in the parenthetical comment that accompanies the first mention of a film, followed by the original title (with English translation for German titles), director and release date.

${ }^{27}$ RGASPI f. 17, op. 125, d. 576, 1l. 57-58 (letter from N. A. Mikhailov to A. A. Kuznetsov and M. A. Suslov, 7 October 1947).

28 Turovskaya, "The 1930s and 1940s: Cinema in Context," 51. There were, however, far more copies of the Soviet-made film, meaning that it took first place at the box office with $30 \%$ more ticket sales overall. 29 These averages are based on available box office data, representing 12 out of 86 trophy films and 26 out of 89 Soviet-made features during 1947-52. For trophy box office rates, see Sergei Kudriavtsev, "Poseshchaemost' otechestvennykh i zarubezhnykh fil'mov v sovetskom kinoprokate," Kinanet.livejournal.com, accessed February 4, 2014, http://kinanet.livejournal.com/689229.html. For Soviet feature box office rates, see Sergei Zemlianukhin and Miroslava Segida, eds., Domashniaia sinemateka: otechestvennoe kino 1918-1996 (Moscow: Dubl'-D, 1996).
} 
rejection of 13 screenplays and rewriting of two more represented losses of 720,000 rubles. Similarly, costs for reshooting and re-editing four Kiev studio productions that same year amounted to three million rubles, at a time when the average black and white feature cost four to five million rubles and color films, eight to ten. ${ }^{30}$

Trophy films did of course require censoring, yet the task was more straightforward in many ways than with Soviet-made feature films. The ideological brigades established to search out potential releases had thousands of films from which to choose, meaning that they could be rigorous in excluding films without costing the Ministry of Cinema in terms of investments in script-writing or filming. Trophy film censorship also required fewer stages: edits were simply planned and executed, and the final product approved for release or excluded if deemed unsatisfactory. ${ }^{31}$ Unforeseen challenges in transforming the film to meet Soviet standards were resolved within the Gor'kii studio editing department, rather than involving the Artistic Council of the Ministry of Cinema (or khudsovet), the Ministry of Cinema itself, and/or Central Committee, as was the case for domestic productions. ${ }^{32}$ It was impossible to order reshoots, thereby closing off another expensive avenue often traversed by Soviet censors. Trophy films also avoided what were arguably the most sensitive topics for Soviet censorship: contemporary Soviet reality and positive heroes. Countless scripts and films were abandoned during the postwar years due to insufficiencies in representing these two features - a factor neatly sidestepped by trophy films. Finally, artistic standards were also slackened for trophy films. Disjointed editing, problems in continuity, poor dialogue, weak plot — all such shortcomings could be attributed to the original film studio and taken as evidence of the inferior quality of bourgeois cinema. In fact, during the war, US Ambassador Averell Harriman observed that Soviet film technicians dubbed and edited (licensed)

\footnotetext{
${ }^{30}$ Laurent, L'œil, 230, 171.

${ }^{31}$ RGASPI f. 17, op. 132, d. 250, 1l. 35-36 (L. F. Il'ichev and A. Maslin to Malenkov, 28 March 1949; Bol'shakov to Malenkov, 25 April 1949).

32 Nelli Morozova, “A sud'i - kto?," Iskusstvo kino 1 (1994): 141-42.
} 
Hollywood films so poorly as to indicate "either gross incompetence or deliberate bungling". ${ }^{33}$ Poor quality was acceptable for trophies, in stark contrast to expectations for Soviet-made features. Finally, the simplified censorship process meant that trophy films were also quicker to produce. In just under seven months, thirty-seven of the fifty trophy films earmarked for processing in August 1948 had been edited, copied and distributed, while eleven more were nearly ready for Soviet audiences. ${ }^{34}$

To summarize, there were several pragmatic advantages to screening captured foreign films after the war. They entertained audiences during a dearth in domestic production, while drawing much-needed revenue from willing viewers - all at negligible cost to the Ministry of Cinema. Based on this analysis, one might well echo novelist Vasilii Aksenov in his claim that " $[\mathrm{t}]$ he authorities, looking for a way to bring in money, decided to swallow their ideological pride and release [trophy films] for public consumption." 35 However, this would be a hasty conclusion. Far from swallowing their ideological pride, Soviet authorities saw in trophy films the opportunity to bolster claims of superiority by demonstrating the universality of key tenets of the Soviet worldview, thereby combining entertainment (and profitability) with political education.

\section{The Ideological Potential of Trophy Films}

In fact, the leadership had been interested in this issue of the hidden ideological potential of certain Hollywood films several months before they numbered among the spoils of war. In late 1944, the Soviet leadership abruptly suspended the lively wartime film exchange with Washington and instead pursued a deal directly with Hollywood film studio RKO Pictures. The intention was to acquire films that Washington had been unwilling to trade- films that

\footnotetext{
${ }^{33}$ J. D. Parks, Culture, Conflict and Coexistence: American-Soviet Cultural Relations, 1917-1958 (London: McFarland, 1983), 96.

${ }^{34}$ RGASPI f. 17, op. 132, d. 250, 1. 35. The remaining two and, as it transpired, also one of the eleven were eventually excluded from the list. (RGASPI f. 17, op. 132, d. 250, 1. 36.)

35 Aksyonov, In Search of Melancholy Baby, 17.
} 
showed America in a negative light - and gain greater latitude in editing the films to suit Soviet educational aims. ${ }^{36}$ The ploy ultimately failed in early 1945, but the Reichsfilmarchiv trophies offered the opportunity to put the plan into action. The result was the release of scores of films processed in such a way as to foreground their instructive value to Soviet audiences. This was achieved through careful selection, editing and presentation oriented toward highlighting, intensifying, and at times manufacturing social and political critique in the Western films.

Each of these processes warrants closer consideration, beginning with selection. It is unclear who initiated the first six trophy releases in early $1947,{ }^{37}$ although Bol'shakov credited Stalin with choosing the two Hollywood productions, Escape from Chains (Pobeg s katorgi; I am a Fugitive from a Chain Gang, LeRoy, 1932) and Senator (Mr. Smith Goes to Washington, Capra, 1939). ${ }^{38}$ Stalin remained involved intermittently in the selection process, ${ }^{39}$ and likely weighed the foreign films according to their ideological content prior to supporting their release. After all, despite his own love for Westerns, Stalin condemned their problematic ideology and ultimately only five were approved for release, making Westerns one of the least represented genres of trophy film. ${ }^{40}$ The majority of titles, however, were selected by Bol'shakov's ideological brigades on the grounds of their either neutral or complementary ideology. Musicals in particular were deemed apolitical (neitral'nyi) and therefore harmless by Bol'shakov and later also Agitprop functionaries V. S. Kruzhkov and A. N. Sazonov - a position

36 Parks, Culture, Conflict and Coexistence, 96-97. Although it was standard practice across Europe to edit Hollywood films, Washington was more wary of Soviet intentions and sought to limit editing rights. ${ }^{37}$ Mikhail Sul'kin, "'Trofeinoe' kino?...Net, vorovannoe. Sovetskie kinotrofei v Amerike,” Iskusstvo kino 9 (2002): 132. Turovskaia credits a screenwriter and Ministry of Cinema functionary named Makliarskii with the idea, but does not elaborate or cite sources. Turovskaia, "Gollivud v Moskve," 59.

${ }^{38}$ RGASPI f. 17, op. 125, d. 576, 1. 60 (Bol'shakov to Kuznetsov, Suslov, and Voroshilov, 27 October 1947).

${ }^{39}$ For instance, Stalin instigated the distribution of Meet Fohn Doe (Poznakom'tes's Dzhonom Dou, Capra, 1941) in 1951 and pronounced the final word on the proposed four-fold Tarzan film release in 1952. RGASPI f. 17, op. 133 (Agitprop), d. 341, 1. 40 (Dokladnaia zapiska o trofeinom amerikanskaia fil'me 'Poznakom'tes c Dzhonom Dou' to Malenkov, 15 August 1951), reprinted in Anderson and Maksimenkov, Kremlevskii kinoteatr, 881. Arkhiv Prezidenta Rossiiskoi Federatsii (AP RF) f. 3, op. 35, d. 74, 11. 90-94 (letter to A. N. Poskrebyshev from Bol'shakov, 31 January 1951), reprinted in Irina Kondakova, "Tarzan -- chelovek, ne isporchennyi burzhuaznoi tsivilizatsiei," Istochnik 4 (1999): 100.

40 Alan Ball, Imagining America: Influence and Images in Twentieth-Century Russia (Oxford: Rowman \& Littlefield Publishers, 2003), 87; Knight, "Stalin’s Trophy Films." 
presumably accepted by the Secretary of the Central Committee who oversaw Agitprop, Andrei Zhdanov, and Malenkov to whom the claims were made. ${ }^{41}$ Such films were valued for their musicality (muzykal'nost') and dance performances, ${ }^{42}$ implying that the Soviet appreciation for the arts transcended national divides.

The remaining films were selected for their potential to coincide with the Soviet portrayal of the West and its history. For example, the first three titles listed on the 31 August 1948 resolution were anti-British films produced under the Nazis, to which three more were later added. A similarly small minority championed revolutionary causes, such as the "struggle of the Mexican people for democracy" in Captain of the Army 'Freedom', ${ }^{43}$ and the Hungarian revolution of 1848 in Maria Ilona (1948; Bolvary, 1939), a heroine praised by Bol'shakov for sacrificing romantic love in the name of her country. ${ }^{44} \mathrm{~A}$ range of historical biographical films on the various "classical and 'progressive' foreign cultural figures" 45 for whom there was official approval — including Liszt, Schumann, and Paracelsus - also featured among the releases.

Most numerous, however, were films about people on the fringes of capitalist society. ${ }^{46}$ Such films echoed what Timothy Johnston identifies as the three central themes of Soviet anti-Western propaganda: workers struggling under economic and racial exploitation; the spuriousness of "capitalist democracy"; and the "soulless, economically driven nature of capitalist society" that rendered "gangsterism" and cynicism rife in the West. ${ }^{47}$ These themes evoked a society divided by exploitation, which was an image that resonated with many Depression-era productions. As Kruzhkov and Sazonov later observed, among the captured

\footnotetext{
${ }^{41}$ RGASPI f. 17, op. 125, d. 576, 1. 3; f. 17, op. 132, d. 429, 1. 55 (letter from V.S. Kruzhkov and A.N. Sazonov to Malenkov, 6 December 1950).

${ }^{42}$ RGASPI f. 17, op. 118, d. 143, 1l. 51-71 (Spisok zagranichnykh kinofil'mov dlia vypuska na zakrytyi i shirokii ekran, 27 August 1948).

43 Ibid., l. 71.

${ }^{44}$ Ibid., 1. 56.

45 Kapterev, "Illusionary Spoils," 788.

46 Laurent, L'œil, 238.

${ }^{47}$ Johnston, Being Soviet, 170.
} 
reels were "films essentially exposing American pseudo-democracy and the anti-popular policies of the imperialist circles of America". ${ }^{48}$ More specifically, Bol'shakov and his team found that The Road of Affliction (Doroga bedstvii, 1948; The Grapes of Wrath, Ford, 1940) presented "two Americas: the flashy capitalist elite, who possess all the wealth of the country, and an enormous proportion of the population who are huddled in miserable hovels, without the means for a piece of bread". ${ }^{49}$ Adaptations of Victor Hugo, Dickens, and Shakespeare were similarly deemed to reveal the oppressions of capitalism. Meanwhile, the Humphrey Bogart crime drama Slums of the Big City (Trushchoby bol'shogo goroda, 1948; Dead End, Wyler, 1937) was recommended for its depiction of the "desperate and hopeless [bezperspektionoe] situation of the inhabitants of the city's outskirts, [and...] American gangsterism", ${ }^{50}$ while boxing film Eighth Round (Vos'moi raund, 1948; The Crowd Roars, Thorpe, 1938) similarly uncovered the "gangsterlike morals and dirty back room dealings of American sports." ${ }^{51}$ Political comedy-dramas like Capra's Senator, Dominated by the Dollar (Vo vlasti dollara, 1949; Mr. Deeds Goes to Town, 1936) and Meet fohn Doe (Poznakom'tes's Dzhonom Dou, 1941) likewise illustrated the Soviet claim that Western democracy was corrupted by "big money" and cronyism - although a degree of creative editing was necessary in order to erase the redemptive message of these films, which ultimately saw the "little man" positively affect the political system. These films, if handled attentively, provided prime material with which to critique the unenlightened anti-humanism of capitalism and imply a contrast with Soviet culture by defining it in terms of what it was not: divided, corrupt, exploitative, soulless and cynical.

Combined with careful film selection was scrupulous editing in the areas of morality, political ideology, religion and happy endings. An outline of changes to be made accompanied the majority of Bol'shakov's requests to the Politburo for approval to release

\footnotetext{
48 RGASPI f. 17, op. 132, d. 429, 1. 55.

49 RGASPI f. 17, op. 118, d. 143, 1. 63.

50 Ibid., l. 71.

${ }^{51}$ Ibid., 1. 66.
} 
films,${ }^{52}$ and provides rich material for the analysis of Soviet editing strategies. In terms of morality editing, films were purged of vulgarity and excessive violence. Content deemed vulgar (poshlyi) included photographs of a character's mistresses, lewd movements in a ballet performance, a peeping Tom, cross-dressing, a cheeky song, and multiple scenes of revelry (kutezh), while a scheming, adulterous Russian character underwent nationality reassignment. Gor'kii studio editor Nelli Morozova, who implemented the changes to trophy films that were outlined by censors, recalls that measures to defend Soviet chasteness were even more thorough than Bol'shakov's notes indicate, and required the removal of frames featuring "the legs of a dancer, a tutu whirling up, a lingering kiss, a beautiful woman in a see-through dress." ${ }^{" 53}$ Instances of murder and torture were earmarked for excision as well, while violent sequences were shortened.

Alterations to the political content of the films centered primarily on the removal of scenes that depicted monarchical and colonial authority in benevolent terms. To this end, Napoleon III, one of the Habsburgs, an Australian governor, and two English kings were stripped of their characterization as honorable rulers intent on justice for their people. Positive portrayals of America and Americans in an international context were also jettisoned from several films, along with philosophical sentiments not in keeping with socialist realism, such as a conversation on the incompatibility of art and reality in the German biopic of Robert Schumann. Among the most precise descriptions of edits to be made were those removing material of a religious or mystical nature. Prayer, religious rites, and special effects implying spiritual intervention were systematically excluded, while John Doe was stripped of his Christian values. ${ }^{54}$

\footnotetext{
52 Ibid., 1l. 51-71; RGASPI f. 17, op. 133, d. 341, 1. 40, reprinted in Anderson and Maksimenkov, Kremlevskii kinoteatr, 881.

53 Morozova, "A sud'i - kto?," 141.

${ }^{54}$ RGASPI f. 17, op. 133, d. 341, 1. 40.
} 
The most intriguing variety of edit, however, dealt with the irrepressible happy ending for which Hollywood and UFA - the German film factory - were well-known. Protagonists were repeatedly left to languish in relational strife as reconciliations were circumvented and weddings cancelled by Soviet censors. Meanwhile, the British people were twice denied the climactic pledge of an incumbent king to right the wrongs of his predecessor. In a feat of editing that would have impressed montage experimentalist Lev Kuleshov, a courtroom full of oppressed Americans was made to protest the heroic Mr. Deeds' imprisonment rather than celebrate his exoneration when the outcome of the trial was reversed by censors in Dominated by the Dollar. Rather than closing with a kiss, the Soviet version ended with a shot of the hero in prison, crafted by repeating a frame from earlier in the film in which Mr. Deeds sat at a window covered over with chain link fencing. ${ }^{55}$ These examples demonstrate that far from releasing trophies hastily, bent solely on profit, the Ministry of Cinema and Politburo paid close attention to the content of trophy films, enlisting skilled technicians like Morozova to recast the Hollywood dream into a capitalist nightmare.

Trophy films that could not be edited satisfactorily were dropped from production, demonstrating the regime's willingness to forego potential profit in the interest of releasing cinema deemed suitable for Soviet audiences. For example, the list compiled by Bol'shakov in August 1948 originally consisted of 70 films, 19 of which were charged with being "politically alien or artistically shoddy" by the Agitprop representatives who screened them. ${ }^{56}$ Among the blacklisted, were films deemed racist, such as Last of the Mohicans (Seitz, 1936) and two German productions; imperialist, like German biopic Carl Peters (Selpin, 1941); or erroneous in their representation of revolution or history, such as The Good Earth (Franklin, 1937) and

\footnotetext{
55 Morozova, "A sud'i - kto?," 141-42.

${ }^{56}$ RGASPI f. 17, op. 132, d. 92, 1.11 (report from D. T. Shepilov and Il'ichev to Malenkov, received 11 August 1948). Apparently Agitprop ran out of time and did not watch the final film.
} 
Cardinal Richelieu (Lee, 1935). ${ }^{57}$ Others were too Christian, militarist, or capitalist, including: The Crusades (DeMille, 1935), criticized for its characterization of Richard the Lionheart as a man of faith; Test Pilot (Fleming, 1938), which championed American military strength in the air; and Captain Fanuary (Butler, 1936), a film so pervaded by the kindness of a capitalist that it could not be corrected, presumably even by removing the happy ending. ${ }^{58}$ The moral quality of the films was also under close inspection, with loose morals, pornographic images, or vulgarity accounting for the majority of the German films struck from processing. Further criticism for poor production values and acting sealed the fate of over half of these discarded trophies, revealing that Agitprop vetted the films according to both ideological appropriateness and entertainment value. However, only three films were dismissed solely on artistic grounds, with the concern that they would not appeal to Soviet audiences, demonstrating that political, religious and moral shortcomings were more salient a cause for withholding a film from Soviet release. These 16 ideologically-based exclusions represented a loss of 630-710 million rubles in potential profit, if Ministry of Cinema estimates of revenue per film are considered. ${ }^{59}$ Meanwhile, actual losses were incurred when three more films initially approved in August 1948 were later abandoned at Bol'shakov's request because the planned edits failed to produce a suitable Soviet version. ${ }^{60}$ Tellingly, these financial losses are not even mentioned in the archival record.

The refashioning of Western cinema to coincide with the Soviet perspective on capitalist society did not end with the processing of the films, but also pertained to their presentation. The majority of the films were presented as evidence of the military superiority

\footnotetext{
57 Incidentally, Cardinal Richelieu was later absolved of its historic inaccuracies and approved for release in November 1952. Ministerstvo kul'tury SSSR, "Catalogue of Foreign Sound Films Released on the Soviet Screen, 1927-1954," 147.

${ }^{58}$ RGASPI f. 17, op. 132, d. 92, 1l. 16, 17, 19, 20 (Zagranichnykh kinofil'mov, kotorye ne sleduet vypuskat' na sovetskii ekran, received 11 August 1948).

59 Six of the 16 were American films and therefore destined for closed screen release, which meant an expected profit of 30-35 million rubles each, while the remaining 10 were for wide release, with expectations of 45-50 million ruble profits each. Ibid., 1. 12.

${ }^{60}$ RGASPI f. 17, op. 132, d. 250, 1l. 35-36.
} 
of the Soviet Union, as the opening credits were removed and replaced with a notice explaining the victorious provenance of the film: "This film was captured as a military trophy during the Great Patriotic War."61 Efforts were also made to "orient the viewer properly" regarding the interpretation of the films, through "carefully edited" explanatory texts prefacing and defining each film in ideological terms. ${ }^{62}$ For instance, the John Wayne vehicle The Fourney will be Dangerous (Puteshestvie budet opasnym, 1948; Stagecoach, Ford, 1939) opened with the warning that,

$[\mathrm{t}]$ his film speaks about the customs of American bourgeois society, and the hypocrisy and bigotry that are its hallmark. It is not difficult for the Soviet viewer to see that the film depicts the American colonial policy towards Indian tribes inaccurately. ${ }^{63}$

What was effectively a revenge thriller was transformed into an argument against colonialism, as the focus was shifted from John Wayne as an individual seeking justice for his father's murder to settlement policies in the American West. The notices prior to the Tarzan films were less prescriptive, consisting mainly of a straightforward plot summary (somewhat of a spoiler in the case of the first film). However, each opening text also included the assertion that, "Tarzan, as a man unspoiled by bourgeois civilization, opposes himself to the cruel and greedy American and British business dealers". ${ }^{64}$ This description invested the Ape Man with

\footnotetext{
${ }^{61}$ Brodskii, "Trofeinoe (1986)," 418. This was the case for the 79 films released in 1948-49, while the six 1947 releases apparently retained their credits, and later screenings opened with the less patriotic (and misleading) announcement that the film was a "new foreign picture". See: Harrison Salisbury, Stalin's Russia and after (London: Macmillan, 1955), 268. Bol'shakov assured Zhdanov in 1947 that Marika Rökk's name was clearly emblazoned at the start of Girl of my Dreams, invalidating rumors that the German musical starred Hitler's mistress Eva Braun. (RGASPI f. 17, op. 125, d. 576, 1l.1-3 [letters from V. P. Stepanov to Zhdanov, 11 February 1947 and Bol'shakov to Zhdanov, 14 March 1947].)

62 RGASPI f. 17, op. 132, d. 92, 1. 11. The USSR was not alone in this practice. The British Board of Film Classification prefaced screenings of The Fall of Berlin (Padenie Berlina, Chiaureli, 1950) in the UK with an opening text indicating the film's bias. Tony Shaw, British Cinema and the Cold War: The State, Propaganda and Consensus (London: Tauris, 2001), 187.

${ }^{63}$ Russian original quoted in Sul'kin, "'Trofeinoe' kino?”

${ }^{64}$ AP RF f. 3, op. 35, d. 74, 1l. 90-94, reprinted in Kondakova, "Tarzan -- chelovek, ne isporchennyi burzhuaznoi tsivilizatsiei," 100-101.
} 
the characteristics of a socialist realist positive hero in the "spontaneous" stage of political development.

The new titles given to many of the films likewise tended to indicate how they were to be understood. As Richard Stites points out, Fate of a Soldier in America (Sud'ba soldata v Amerike), the new title of the prohibition gangster film The Roaring Twenties (1952; Walsh, 1939), "underlin[ed] capitalist heartlessness toward veterans" 65 by transmuting the exceptional challenges faced by Bogart into the typical experience of Great War veterans. Other titles such as Dominated by the Dollar, Requital (Rasplata [which can also be translated "payment"], 1948; The Count of Monte Cristo, Lee, 1934) and Stronger Dollar (Sil'nee dollar, suggested by Bol'shakov [read: Stalin] for Meet Fohn Doe but ultimately abandoned ${ }^{66}$ ) transformed a minor plot point into the primary theme of the film, and fabricated a preoccupation with wealth that was arguably absent from the original pictures. ${ }^{67}$

While introductory texts and titles framed the individual film, the press framed the phenomenon of Western cinema as a whole by providing the Soviet audience with unceasing reminders as to the inferiority of bourgeois cinema in comparison to socialist realist film production. This tendency was particularly marked in Iskusstvo kino, the sole cinema periodical at the time, which in one issue alone featured derogatory analyses of Western (and particularly American) film by Vsevolod Pudovkin, Sergei Gerasimov, and screenwriter Boris Chirskov. ${ }^{68}$ Even Bol'shakov contributed to the discussion when he announced the complete ideological and artistic domination of Soviet cinematography over that of the West at international film festivals in France, Italy and Czechoslovakia. ${ }^{69}$ This constant barrage of

\footnotetext{
${ }^{65}$ Richard Stites, Russian Popular Culture: Entertainment and Society Since 1900 (Cambridge University Press, 1992), 125.

66 RGASPI f. 17, op. 133, d. 341, 1. 40.

67 Stites claims that films were also accompanied by "ideological lectures to explain their 'real' meaning", although this has not been mentioned by any other source. (Stites, Russian Popular Culture, 125.)

68 Vsevolod Pudovkin and E. Smirnova, "Pobeda Bol'shevistskoi pravdy," Iskussto kino 6 (1949): 16-18; Sergei Gerasimov, "Sila Stalinskikh idei," Iskusstvo kino 6 (1949): 13-15; Boris Chirskov, "Nas uchit partiia," Iskusstvo kino, 1949, 22-26.

${ }^{69}$ Ivan Bol'shakov, "Tridtsat' let Sovetskogo kino," Iskusstvo kino, 1950, 7.
} 
criticism as to the poor artistic quality and ideological illegitimacy of Western cinema reinforces the notion that trophy films were not intended simply for entertainment, but rather provided a window onto a corrupt system through both their content and their supposedly poor production values.

This theme was also developed by the first of only two press articles to acknowledge the existence of trophy films, a piece in Kul'tura i zhizn' dedicated to Girl of my Dreams in March 1947 before it was screened on wide release. The article consisted primarily of viewer responses to the film (discussed further below), but opened with this telling statement: "This film, considered the best work of German cinematography, is a clear example of the complete spiritual emptiness and moral decline of bourgeois cinema art."70 The second article, penned by Komsomol head Nikolai Mikhailov and printed in Komsomol'skaia pravda in October 1947, criticized Bol'shakov and his Ministry for the supposed dominance of foreign (trophy) films on Soviet screens, calling instead for increased Soviet film production. ${ }^{71}$ Bol'shakov responded forcefully to this criticism, involving Kliment Voroshilov (then head of the bureau for culture under the Council of Ministers) in reprimanding Mikhailov and his publication in order to prevent them from further "disorienting" (dezorientirovat') the Soviet public. ${ }^{72}$ Subsequently, the press refrained from mentioning trophy films. Critiques of bourgeois cinema studiously avoided naming films released from the trophy collection, even while discussing others that no doubt formed part of the collection. Chirskov, for example, concentrated his ire upon Citizen Kane (Welles, 1941), Goodbye, Mr. Chips (Wood, 1939) and Cavalcade (Lloyd, 1933), all of which were likely part of the Reichsfilmarchiv given their significance and years of production, though none were screened publicly.

\footnotetext{
70 "Sovetskie zriteli o fil'me 'Devushka moei mechty," Kul'tura i zhizn', March 21, 1947.

71 Ibid.; Nikolai Mikhailov, "Pochemu kinoekrany stanoviatsia provodnikami burzhuaznoi morali?," Komsomol'skaia pravda, October 18, 1947.

${ }^{72}$ RGASPI f. 17, op. 125, d. 576, 1l. 59-60.
} 
The silence of the press on trophy films was not solely the result of Bol'shakov's intimidation tactics. Instead, there were several reasons why the press was not mobilized to elaborate explicitly on the place of trophy films within the regime's anti-Western campaign, not least being the illegal nature of the American film screenings. Press coverage would only draw the attention of American observers - who scrutinized the Soviet press closely 73 - to the unlicensed screening of Hollywood films, and risk prompting a retaliatory boycott of Artkino, the company that distributed Soviet cinema in America. ${ }^{74}$ Film promotion in general was also at a low point during malokartin'e, and even many Soviet releases failed to generate significant coverage. An October 1947 resolution barring the publication of information about films not yet released limited press coverage of cinema and implicitly encouraged film critics to let Pravda establish the tone of the discussion. Arguably, Pravda remained silent on trophy films because of an appreciation for the fineness of the line that the regime trod between the ideological hazard and potential inherent in airing enemy films. As Pamela Kachurin and Musya Glants observe with regard to the Cold War, "[t]he potential for conflicting or ambiguous interpretations made it difficult to use cultural products efficaciously as forms of propaganda." 75 For although bourgeois films were (supposedly) ideologically and artistically inferior, emphasizing these flaws too strenuously risked prompting audiences to question why they were being screened at all if they were so morally and spiritually vacuous. This is why a public critique of trophy films like Mikhailov's was reprimanded decisively: his article truly did "disorient" the viewing public.

\footnotetext{
73 The New Tork Times regularly printed stories drawn from the Soviet press, such as the account of the ban against photographs of Hollywood actors like Clark Gable. See Associated Press, "Hollywood Stars' Photos Barred in Soviet Union," New York Times, January 8, 1948. February 1949 saw the first edition of the weekly journal Current Digest of the Soviet Press that surveyed an impressive breadth of Soviet periodicals, translating dozens of articles in each issue, with regular coverage of Soviet cinema.

${ }^{74}$ RGASPI f. 17, op. 132, d. 92, 1.5 (O vypuske na nashi ekrany Amerikanskogo fil'ma 'Viva Villa', 5 August 1948).

75 Pamela Kachurin and Musya Glants, "Special Issue: Culture, the Soviet Union, and the Cold War," Journal of Cold War Studies 4, no. 1 (2002): 5.
} 
Ultimately, the release of these films was a gamble deemed worthwhile. As the anticosmopolitanism campaign intensified and the Soviet economy recovered, trophy film releases persisted, even outlasting Stalin. ${ }^{76}$ Whether or not the risk bore dividends for the regime with the viewing public, however, is another issue altogether, and one to which we now turn.

\section{Responses to Trophy Films}

The issue of reception is complicated by the scarcity of sources and their disparity in type and origin. Recorded responses to trophy film come from a range of Soviet, former-Soviet, and post-socialist sources: from politically correct Party activists and letter writers addressing their concerns to newspaper editors and officials at the time; to contemporaneous Soviet émigrés interviewed by the Harvard Project on the Soviet Social System and former Soviets interviewed by Western scholars since the collapse of that system; to leading cultural figures and memoirists writing from abroad - like Aksenov and poet and essayist Iosif Brodskii — or during the final days of perestroika, like poet Bulat Okudzhava. The picture that emerges from this patchwork of sources is predictably varied. Trophy films were both rejected and revered, considered lightly and scrutinized closely, taken as pure entertainment and as truth about the outside world. Such diversity of responses is in fact typical of late Stalin era film reception, ${ }^{77}$ and is testament to the complexity of the experiment to integrate entertainment and ideology. As will emerge in the following analysis of negative and positive viewer responses, part of the danger of merging political education and entertainment was the potential for audiences to overlook the lesson. Yet it was in this very risk that the benefit also lay: namely, the possibility of shaping the perceptions and prejudices of the public without their awareness.

\footnotetext{
${ }^{76}$ Elena Kartseva, “Amerikanskie fil'my na rossiiskikh kinoekranakh,” Kinograf, no. 16 (2005): 208-17; Kapterev, "Illusionary Spoils," 806. cf. Kenez, Cinema and Soviet Society, 214.

77 See, for example, the case of Pyr'ev's Kubanskie kazaki (1950) in Rimgaila Salys, The Strange Afterlife of Stalinist Musical Films (Washington, D.C.: National Council for Eurasian and East European Research, 2003).
} 
Despite their popularity at the box office, trophy films were not greeted with unanimous favor. The press coverage discussed earlier referred to letters of complaint received by the editors of Komsomol'skaia pravda and Kul'tura $i$ zhizn', with the latter printing excerpts that deplored Girl of my Dreams as a "typical bourgeois, vulgar film" with "alien music-hall morals and music-hall heroes". It was "not only unprincipled, but also harmful. [For...] after a deadly war against the fascist barbarians, after the horrific devastation and the enormous sacrifices of the Soviet people, they show starry-eyed [prekrasnodushnykh] Germans." Others echoed this complaint, stating that "this is not the girl of our dreams! We do not need such a thing!" and holding instead that such were the "dreams of fascist youths". ${ }^{78}$ It is no surprise that a third of the complainants are identified by their military rank. Another third are identified as students, at least one of whom was involved in the petition signed by 150 Physics students at the Leningrad State University demanding the removal of the film from the screen. ${ }^{79}$ Young people were likewise implicated in the denunciation of trophy films later that year at meetings organized by the Komsomol. Held in the wake of the honor court trial of cancer researchers Nina Kliueva and Grigorii Roskin, the meetings censured young people for various behaviors perceived as pro-Western, which included demonstrating a fondness for Girl of my Dreams. ${ }^{80}$

There is only limited archival evidence of continued popular opposition to trophy films, consisting of a brief report and an anonymous letter. The report from deputy head of Agitprop L.F. Il'ichev, ${ }^{81}$ warned of a large quantity of complaint letters received in 1948 by the editors of central newspapers from workers concerned with the ideological content of trophy films - or more precisely, based on Il'ichev's examples, German and Czech films. The Czech film Rescued Banners (Spasennye znamena, 1948; Port Arthur, Farkas, 1936), set during the Russo-

\footnotetext{
78 "Sovetskie zriteli."

${ }^{79}$ RGASPI f. 17, op. 125, d. 576, 1. 1; Ibid.

80 Fürst, Stalin's Last Generation, 72.

81 Il'ichev was the editor of Izvestiia at the time, and also the head of the khudsovet.
} 
Japanese War, came under particularly heated attack as the antithesis of recent Soviet achievements in art and for its poisonous, hostile ideology. One Leningrader even decried it as a sign of the depths to which "patriotic cinematography" had fallen in allowing foreign films access to the crucial "Russian weapon" of the silver screen. ${ }^{82}$ In 1950, another such letter crossed Malenkov's desk, this time sounding the alarm against the covert ideological messages of Hollywood. The author pointed out, for example, that Van Dyke's Rose-Marie (1949; 1936) demonstrated the honorable character of the American police (although the film is about a Canadian Mountie), and dealt a "blow to the defense of the Soviet state, undermining its psychological and ideological power in a possible future war."83 Similarly, Deanna Durbin films such as The Actress' Secret (Sekret aktrisy, 1948; Mad about Music, Taurog, 1938) and First Ball (Peroyi bal, 1948; First Love, Koster, 1939) maintained that "the poor but honest person always finds happiness in America — without revolutionary protest demonstrating the life of fun led by the American youth, etc." 84 The author was clearly wellversed in current affairs and cultural campaigns, even referring to the Cold War as an artistic struggle. Nevertheless, when forwarding the letter to Malenkov, Agitprop officials dismissed the author's concerns decisively, and Malenkov ordered the matter closed. ${ }^{85}$ Although it is impossible to discern the extent of popular opposition to trophy films from these sources, it is plain that the Soviet leadership did not consider it sufficient grounds to remove the films from circulation.

There is much more to be drawn from the viewer responses recorded in memoirs and interviews, which were markedly positive. It is from these sources that scholarship has gained a sense of the general popularity of the films - from accounts such as that of Okudzhava, who describes how

\footnotetext{
${ }^{82}$ RGASPI f. 17, op. 132, d. 92, 1l. 63-64 (Il'ichev to Malenkov, received 4 November 1948).

83 RGASPI f. 17, op. 132, d. 429, 1.51 (reverse) (Anonymous letter to the Central Control Commission of the Party, circa November 1950).

84 Ibid., 1. 52 (front).

85 Ibid., l. 55.
} 
[n]ormal life stopped in the city. Everyone talked about the film [Girl of my

Dreams], they ran to see it whenever they had a chance, in the streets people

whistled melodies from it, from half-open windows you could hear people

playing tunes from it on the piano. ${ }^{86}$

The recollections of former stiliagi (stylish ones) of the youth sub-culture that blossomed during the late 1940s and 1950s are particularly fruitful on the subject of trophy films.

Research and interviews conducted by scholars of the youth movement have

highlighted the importance of the trophies as conduits for the jazz music and Western

dances, fashion and hairstyles that so captivated the stiliagi. ${ }^{87}$ Aksenov, a former stiliaga

himself, describes how the subtitled Hollywood films even furnished them with a

vocabulary, as he and his friends spoke to one another "almost entirely in quotes from

American movies". ${ }^{88}$ Meanwhile, self-declared "stylish man Number One" Tikhonenko

recalls modeling his wardrobe on trophy film heroes, even purchasing a Stetson hat in

order to better advertise his wares as a black marketer. ${ }^{89}$ The Tarzan films in particular

generated a cult following as boys and young men adopted the longer coif sported by

Johnny Weissmuller - although young women opted to model their hairstyles after

Marika Rökk and Deanna Durbin rather than Tarzan's Maureen O'Sullivan. ${ }^{90}$ Tarzan

provided no end of entertainment outside the cinema as well, as children played

"Tarzan and Cheetah" in the courtyards and frightened cows on the kolkhozy with their

\footnotetext{
${ }^{86}$ Quoted in Kenez, Cinema and Soviet Society, 214. For the original, see: Bulat Okudzhava, "Devushka moei mechty," 1991, 3, http://userdocs.ru/voennoe/50647/index.html.

87 Edele, "Strange Young Men in Stalin's Moscow," 56; Stites, Russian Popular Culture, 125; Fürst, Stalin's Last Generation, 209, 237; Gleb Tsipursky, "Young Jazz Enthusiasts and the Cultural Cold War in the Soviet Union, 1948-53" (Music and Power Symposium, Miami University, 2013), 8, http://www.units.muohio.edu/havighurstcenter/events/Music_PowerSymposium.html.

88 Aksyonov, In Search of Melancholy Baby, 18.

${ }^{89}$ Guk, "Tarzan v svoem otechestve: Valentin Tikhonenko."

${ }^{90}$ Eduard Shim, "Ready, Heave!," Current Digest of the Soviet Press 19, no. 15 (1967): 12; Fürst, Stalin's Last Generation, 207; Brodskii, "Trofeinoe (1986)," 419.
} 
Ape Man yells (allegedly reducing milk production), while older youths drew upon the dialogues between the jungle king and his lady love for strategies in courting. ${ }^{91}$

In a memoir of his years in Moscow, New York Times correspondent Harrison Salisbury interprets the popularity of Tarzan and other trophies as evidence of the need for escapism in postwar Soviet society - a correlation that social historian Juliane Fürst also highlights. ${ }^{92}$ Using testimonials from young viewers preserved in the Komsomol archives, Fürst points out that they "valued foreign films because of their 'ability to address a light subject that entertains the viewer, gives him rest and instills in him the feeling of something beautiful'."93 Johnston notes a similar theme in his interviews as, for instance, "Natalia Leonidovna reminisced about foreign movies that, '...everyone wanted to look at something beautiful and bright, it was pleasant'. Svetlana Ivanovna also remembered that '...the foreign films had beautiful costumes and people in them. They were very good."'94 In other words, the ideological message of Sovietized foreign films did not necessarily factor into the viewing experience. Indeed, Stites found that when questioned in 1990, Leningrad audiences "recalled the fact but not the messages of the propaganda lessons that preceded" the films. ${ }^{95}$ Similarly, of the nearly hundred Harvard interview project respondents who mentioned foreign films (in overwhelmingly positive terms), only a handful demonstrated any awareness that the films had been deliberately selected, censored, or otherwise processed by officials. ${ }^{96}$ Instead, trophy films were above all, entertaining.

These glimpses into popular reception provide compelling evidence for the seeming failure of attempts to exploit entertaining trophy films to convey Soviet ideology. According to these sources, trophies were at best escapist and at worst, anti-Soviet, while the warning

\footnotetext{
${ }^{91}$ Roth-Ey, Moscow Prime Time, 42; Salisbury, Stalin's Russia and after, 268.

92 Salisbury, Stalin's Russia and after, 268.

93 Fürst, Stalin's Last Generation, 207.

${ }^{94}$ Johnston, Being Soviet, 206.

95 Stites, Russian Popular Culture, 220.

${ }_{96}$ Respondents 175, 302, 308, 335, 386, 487 and 61 1, "Harvard Project on the Soviet Social System." Of these, only 335 and 487 refer to trophy films specifically.
} 
against the ills of capitalism was apparently unmemorable. Yet the failure of viewers to identify the ideological wrapping in which trophy films were repackaged is not necessarily a sign of the failure of that message. After all, the best learned ideological lessons are those the audience does not realize it has absorbed, which is arguably a key motivation for the synthesis of entertainment and enlightenment in Soviet cultural production. The critiques of capitalism made by trophy films were very familiar to Soviet viewers and may not have warranted particular note, while nevertheless reinforcing a Soviet worldview. At the very least, a handful of Harvard interviewees did recognize that the foreign films screened in the USSR during the 1940s (both trophies and legal imports) were "advantageous to the Soviet power [sic]".97

If the aim was to fan the flames of anti-capitalist sentiment, the Sovietization of these foreign films fell short of the mark. However, if the goal was to sharpen the definition of what the USSR was and was not in the context of cultural conflict, there remains a thread of evidence to support the efficacy of trophy films. This thread, weaving through the full range of viewer responses, is the perception that the films' release was a mistake on the part of the regime. That this was a feature of negative responses is of course no surprise. For instance, Mikhailov opens his condemnatory editorial in Komsomol'skaia pravda with a reminder of the "serious mistakes" committed by the Ministry of Cinema the preceding year (a reference to the Central Committee resolution of 4 September 1946 shelving films by Lukov, Pudovkin, Eisenstein, and Kozintsev and Trauberg), implying that it had done so again with the release of trophy films..$^{98}$ The anonymous complainant of 1950 makes a similar point, questioning the "naïve cinema dealers $[\ldots]$ who do not understand that these films are intended by their creators to contaminate the consciousness of the people." ${ }^{99}$ According to viewers critical of trophies, the regime conceded too much ground to the enemy in screening these films.

\footnotetext{
97 Respondent 308, Ibid.

98 Mikhailov, "Pochemu kinoekrany stanoviatsia provodnikami burzhuaznoi morali?"

${ }^{99}$ RGASPI f. 17, op. 132, d. 429, 1. 54.
} 
Positive responses likewise considered the state to have been in error, albeit for a slightly different reason: they held that trophy films fuelled deviant, if not outright oppositionist behavior among viewers. For instance, Aksenov writes that a friend, after becoming a high-ranking officer in the Soviet Air Force, confided to him that "Comrade Stalin made a big mistake by letting our generation see those films.” Aksenov continues, explaining that "they provided one of the few windows to the outside world from our stinking Stalinist lair", ${ }^{100}$ implying that it was by the light of this window that the stinking lair was revealed as such. The example of Karan Kondikian betrays the perceived danger of staring out of this window too avidly. He recounted to Hollywood producer Tom Luddy that his childhood obsession with Tarzan and persistent questioning at school regarding travel to Africa resulted in his father's internment in the gulag. ${ }^{101}$ Kondikian construed his love for Tarzan as threatening to the regime. Brodskii agrees, crediting the Tarzan films with having "aided de-Stalinization more than all of Khrushchev's speeches to the XXth Party Congress and subsequently." 102 In this manner, even accounts that laud trophy films consider the line between acceptability and transgression too fine to regard them as unproblematic. These reactions implicitly indicate the regime's success in defining Sovietness - what it was and was not - since both viewers who were critical of trophy films and those who greeted them enthusiastically perceived watching trophy films as transgressive. Of course, this small success was overshadowed, however, by the larger failure of Soviet-made films to keep foreign cinema in its place, instead conceding box office triumph to trophy films.

\section{Conclusion}

Trophy film played a pivotal role in sustaining the postwar film industry. The Sovietized foreign films bolstered production rates, fulfilled profit plans, and infused the screen with

\footnotetext{
100 Aksyonov, In Search of Melancholy Baby, 18.

101 Tom Luddy, "My Dinner with Luddy," Mother Fones Magazine, December 1984, 33.

102 Brodskii, "Trofeinoe (1986)," 419.
} 
added generic diversity, maintaining the presence of popular genres that were constricted by censorship after the war. Alongside these tangible results is also the more fraught ideological significance of these films. Scholarship has already noted the influence of trophy films on the youth culture of stiliagi, whom Aksenov credits as the first dissidents. ${ }^{103}$ But what has been explored here is the ideological use to which the regime sought to put these films, and the ways in which they were processed in order that they might contribute to defining Soviet identity. That they did so from a somewhat incongruous, even paradoxical angle - enemy cinema - points to a fundamental characteristic of ideology, namely that it requires dialogue with its opponent. This was not simply an aberration of the cinema industry. As Vladimir Pechatnov explains in his study of Soviet and foreign propaganda during the early Cold War, "in their pursuit of ideological indoctrination the [regime] relied not on the isolation of the Soviet people from Western propaganda, but to some extent on the 'struggle of ideas'.”'104 This is why magazines such as Amerika and British Ally (Britanskii Soiuznik) were permitted to circulate. It is also why, as Johnston observes in his analysis of Cold War Official Soviet Identity, "the most important factor within Soviet identity [...] was the capitalist West, and in particular America" and its cultural production, including film. ${ }^{105}$ American culture provided Sovietness with both a counterpart and antithesis: a standard against which to measure success, and an example against which the uniqueness of the Soviet model was defined. Despite the anti-Western resolutions and rhetoric that proliferated beginning in 1947, Soviet culture could not persist apart from its opponent; for Sovietness to have meaning, there had to be continued interaction with Western culture. Trophy films provided a form of such interaction, albeit one that the regime sought to choreograph closely. In this sense, the cinema industry sought to fashion captured films into trophies not just of the Great Patriotic

\footnotetext{
103 Aksyonov, In Search of Melancholy Baby, 18.

104 Vladimir Pechatnov, "Exercise in Frustration: Soviet Foreign Propaganda in the Early Cold War, 1945-47," Cold War History 1, no. 2 (January 2001): 5.

${ }^{105}$ Johnston, Being Soviet, 167.
} 
War, but of the Cold War as well, marking Soviet victory on both fronts of the cultural conflict. These films were intended to represent the victory of postwar Soviet culture over Western culture. The problem for the regime was that despite its best efforts, Soviet viewers did not always perceive trophy cinema in this way. 